\title{
Fiscal Policy and COVID-19: Insights from a Quantitative Model
}

\author{
Miguel Faria-e-Castro, Economist
}

T he ongoing COVID-19 outbreak and subsequent infection-control actions have disrupted economic activity across the globe. In response, fiscal authorities are designing and implementing stabilization packages to mitigate the effects of rising unemployment and business closures. ${ }^{1}$

In this essay, I describe the analysis in a recent working paper (Faria-e-Castro, 2020) that uses a macroeconomic model to think about the effects of some of these fiscal policies in the event of a pandemic. The model is used to evaluate the effects of five types of policies on household income and consumption. I find that increases in unemployment insurance (UI) most effectively mitigate the effect of a pandemic on household income.

\section{The Model}

My model features two types of households: (i) workerborrowers who earn income from employment and (ii) owner-savers who are wealthier agents who own firms and banks and receive profits from those institutions. Workers can either be unemployed, in which case they receive UI, or employed and work in one of two sectors. The first sector is a "quarantine" sector that is susceptible to disruption due to a pandemic. One can think of these jobs as involving close (or actual) physical contact with other people and hence creating a greater chance for workers and customers of contracting an infectious disease (e.g., restaurants or air travel). The other sector is a non-services sector where activity is not directly affected by the outbreak (but there may be indirect effects).

\section{The Outbreak}

In the model, an outbreak of disease shuts down the services sector. Households, afraid of being infected, stop consuming services that involve close physical contact with other people. ${ }^{2}$ The shock increases the unemployment rate by 20 percent, in line with some projections of current conditions, with most job loss coming from the services sector. ${ }^{3}$ The impact of these losses spills over to the rest of the economy: As services sector workers lose their jobs and income, they have to reduce their consumption of non-services. This, in turn, reduces employment in the other sector.

\section{Policy Responses}

Because the reduction in the demand for services and subsequent slowdown is a consequence of policies-such as social distancing-designed to contain the outbreak, it is not obvious that fiscal policy should be used to offset the effects of this shock on GDP. That is, the government may not want to buy goods or deliver tax cuts to stimulate economic activity if it wants people to stay home precisely to prevent infection. Policy can, however, help contain spillovers to other sectors and stabilize income for affected workers. I consider five types of policies: (i) government purchases, (ii) income tax cuts, (iii) increases in UI, (iv) unconditional transfers, ${ }^{4}$ and (v) liquidity assistance to distressed firms.

Unemployment insurance may be the most effective way to help households right now.

The primary negative economic effect of the pandemic is that it sharply raises unemployment. Policies that transfer resources directly to borrowers - policies (ii) through (iv) are more effective than the others; UI is the best targeted policy of policies (ii) through (iv). Higher UI generates the largest benefit in household income net of transfers per dollar spent by the government. Income tax cuts benefit workers who remain employed, but there are fewer of these workers after the shock. Unconditional transfers benefit everyone, which means that resources are spent on households that do not necessarily need these transfers (i.e., savers). Transfers to the unemployed are, therefore, the best measure because they directly target people who have lost their jobs from the outbreak. Liquidity assistance to affected firms is less effective at stabilizing income (per dollar spent) but is very effective at stabilizing employment 


\section{ECONOMIC Synopses}

in the affected sector. Therefore, governments should consider this instrument to preserve employment.

One important caveat is that I consider only the effects of conventional stabilization policy and do not explicitly model the effects of government investment in the public health response. In the words of Austan Goolsbee, professor of economics at the University of Chicago and former Chair of the Council of Economic Advisers, "...the difference of virus economics from regular business cycle economics is this paradox that the best thing you can do for the economy has nothing to do with the economy."

\section{Notes}

${ }^{1}$ At the time of writing, the U.S. Congress is preparing to pass a $\$ 2$ trillion aid package.

2 A recent paper by Eichenbaum, Rebelo, and Trabandt (2020) embeds an epidemiology model into a macroeconomic model. This allows the authors to explicitly study the effects of public health interventions, such as social distancing and the introduction of a vaccine.

${ }^{3}$ See, for example, this blog post by Federal Reserve Bank of St. Louis President James Bullard: https://www.stlouisfed.org/on-the-economy/2020/

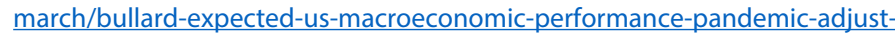
ment-period.

${ }^{4}$ For example, sending a check to every person in the United States.

5 National Public Radio. "Medicine for the Economy." Planet Money (podcast), Episode 979.

\section{References}

Eichenbaum, M.S.; Rebelo, S. and Trabandt, M. "The Macroeconomics of Epidemics." NBER Working Paper No. 26882, National Bureau of Economic Research, 2020.

Faria-e-Castro, M. "Fiscal Policy during a Pandemic." Working Paper 2020-006, Federal Reserve Bank of St. Louis, 2020;

https://research.stlouisfed.org/wp/more/2020-006. 